\title{
Free Trade Agreements: WTO and ASEAN Implications
}

\author{
JOSE L. TONGZON
}

\begin{abstract}
The World Trade Organization (WTO) (formerly GATT) was established primarily to achieve free trade across the globe based on the principle of non-discrimination and the process of multilateral trade negotiations. The fact that most countries are members of WTO reflects the worldwide belief in the benefits of a global free trade. Despite its achievements since the first round of multilateral trade negotiations was held, the effectiveness of the process has been called into question. Most WTO members are now proposing new regional trading arrangements (RTAs), such as free trade agreements (FTAs).

What implication does these RTAs have for the WTO and ASEAN countries? Should ASEAN countries give regionalism priority over the WTO-based multilateral approach? To answer this questions, this paper will first summarize the motivations behind the formation of RTAs before presenting the merits and demerits of RTAs as an approach to achieve universal free trade and maximize developing countries' welfare. It is argued that despite its inherent limitations it is important for ASEAN countries to remain primarily committed to the principles of WTO and the process of multilateral trade negotiations.
\end{abstract}

\section{Why Regional Trading Arrangements (RTAs)?}

There has been a plethora of proposals for new bilateral and regional trade arrangements in recent years. From bilateral agreements such as Singapore-US, Singapore-India, Japan-Korea, Japan-Singapore to regional ones such as ASEAN-China, ASEAN-India, ASEAN+3 and other regional groupings. Up until recently, these countries have only opted for a multilateral and non-preferential route to trade liberalization. Under this approach these countries undertook unilateral liberalization on an MFN basis. However, since the late 1990s there has been a shift from the non-preferential route to trade liberalization. Although few of these proposals have reached negotiation stage or been formalized, it is evident that many economies in the region are seriously engaged in the development of new preferential trading relationships, while others are actively considering moves in this direction. This includes economies 
which were in the past staunchly against the preferential route to trade liberalization, such as Japan and Korea.

These initiatives have come in the wake of a global trend towards regionalism. As a result, most industrial and developing countries in the world are members of a regional trade or integration agreement, and many belong to more than one such agreement. More than one third of world trade takes place within such agreements and if Asia Pacific Economic Cooperation (APEC), a somewhat looser organization comprised of more than twenty high-income, middle-income, and lowincome countries of the Pacific Basin, is included, this figure increases to 59 percent (World Bank 2000: 1).

Although all RTAs are committed to trade liberalization between the members by reducing barriers, they vary in terms of the level of integration. At the base is the Free Trade Agreement (FTA), where trade barriers (usually tariffs) between partner countries are abolished. However, each member independently determines its own external trade barrier with non-FTA members. A prominent example of an FTA is the North American Free Trade Agreement (NAFTA) between US, Canada, and Mexico. The next level of integration is the Customs Union where a common external trade policy is adopted by member countries (e.g., MERCOSUR comprised of Argentina, Brazil, Paraguay, and Uruguay). Common Markets like the European Community adopt further provisions to facilitate free movement of factors of production and harmonization of trading and production standards across member countries. Finally, Economic Unions such as the European Union extend the harmonization to macroeconomic (such as fiscal and monetary) and social as well as legal policies.

There are a number of reasons for this global trend towards regionalism. Despite the substantial tariff reduction on manufactured goods resulting from the WTO-sponsored trade negotiations, there has been a growing dissatisfaction over the multilateral approach to trade liberalization under the auspices of the WTO (formerly GATT) for a number of reasons. New forms of trade restrictions such as the Voluntary Export Restraints (VERs), Orderly Marketing Arrangements (OMAs), technical standards, customs procedures and others have emerged as disguised forms of protectionism. The large membership of the WTO has made negotiations more complicated and difficult to resolve, let alone monitor compliances. The Western countries, particularly Western Europe and the US, are increasingly disillusioned with the slow progress in trade liberalization, and there has been a growing perception that multilateralism has failed to provide a level 
playing field. The Special and Differential treatment (S \& D) accorded to developing countries in the form of the Generalized System of Preferences has been cited as an example.

There has been a perception that the European market is becoming more inward-looking with the establishment of the European Union (EU) and the extension of integration to the European Free Trade Area (EFTA) and Eastern European countries. The decline in US economic dominance and increased competition from Europe and Japan has reduced US commitment to multilateralism and pushed it to form a countervailing bloc. The US-Canada Free Trade Area (FTA) was later followed by the North America Free Trade Area (NAFTA). The enterprise for the Americas' initiative envisages more FTAs with South American countries.

The collapse of the WTO talks in Seattle and recently in Cancun has made countries even more pessimistic about the effectiveness of multilateralism and has driven a number of countries to form regional groupings as an insurance policy. Singapore Trade Minister George Yeo, who was in Cancun for the failed WTO talks said on his return to Singapore that Singapore would seek more bilateral free trade agreements following the breakdown of Cancun (The Business Times, 23 September 2003). He highlighted the importance to Singapore of already signed FTAs with New Zealand, Japan, the EFTA and Australia. He said Singapore intended to sign similar deals with Canada, India, Chile, Jordan and South Korea. Bob Zoellick, America's top trade negotiator, claimed that countries were approaching him to push for bilateral deals even as the Cancun meeting was crumbling (The Economist, 18 September 2003).

More countries may now divert their negotiating energies into bilateral FTAs. After the failure of the Cancun talks, Mr Zoellick said that America would now push on the bilateral and regional route. The United States undoubtedly will push ahead and start new FTA talks with Colombia and Thailand (and maybe Peru and Sri Lanka). These talks were being considered before Cancun, but will be given greater priority. Efforts to deepen North American economic integration, in part for security, could also advance. However, negotiation of the FreeTrade Area of the Americas (FTAA), which requires a convergence of American and Brazilian positions and which is linked substantially to the Doha round, could be set back. ${ }^{1}$

The EU will probably give more attention to problems of enlargement and trade initiatives with Eastern European and Mediterranean countries. The EU also may drop its self-imposed moratorium on new FTA negotiations in order to keep pace with America. Given European 
sensitivities on agriculture, however, there is a big risk that such new initiatives could focus primarily on manufacturing trade and investment, leaving protection for most farm products untouched. But cutting out agriculture means that the stalled EU negotiations with the Mercosur countries - which have proceeded in parallel with the FTAA - may well continue to drift. ${ }^{2}$

In Asia, countries have engaged more aggressively in negotiating FTAs. China is negotiating an FTA with ASEAN, which Japan and India are trying to emulate. Long-delayed trade talks between Japan and South Korea have just been announced. Both are also pursuing other FTAs, though agriculture remains a stumbling block. However, if China proposes moving forward with a North East Asia FTA, it will be hard for South Korea and Japan to resist. For now, an FTA involving East Asia's 'big three' is a long-term vision, not a negotiating initiative - but that could change quickly if the WTO process remains stalled.

Finally, the faltering support of the US and Western Europe for the multilateral system has created a sense elsewhere that regionalism is the order of the day. Smaller countries are seeking RTAs with their large neighbours. Ex-President of Mexico Salinas pushed Mexico into NAFTA because of concern that European investments would be diverted to Eastern Europe and that domestic reforms in Mexico might be derailed under political pressure. On the other hand, there was the US concern with cross-border problems should the Mexican economy collapse.

Due to the above sources of dissatisfaction over WTO-sponsored multilateral approach, there has been a proliferation of regional trading pacts. According to the WTO report (1995), 109 RTAs were submitted to GATT between 1947 and 1994. There were 33 registered pacts between 1990 and 1994. The formation of RTAs worldwide gathered momentum in the past decade. For example, of the total 194 agreements recorded with the WTO at the beginning of 1999, 87 came into existence since 1990 (World Bank 2000: 1). Of some 200 RTAs notified to WTO (or GATT) so far, more than 130 agreements are still in force today.

\section{Stumbling or Building Blocks?}

The question of whether the proliferation of RTAs will lead to global free trade as advocated by the WTO is a relevant but a difficult issue to resolve owing to the co-existence of positive and negative implications of preferential trading arrangements. ${ }^{3}$

That global free trade is more beneficial to countries than regional free trade was advocated by Adam Smith and David Ricardo and later was 
rigorously proved in a number of theoretical studies (for example, Samuelson 1939 and Kemp 1962). Viner's analysis of trade creation and trade diversion has also shown that preferential trading arrangements are not necessarily welfare-enhancing, either from the members' viewpoint or from the world's. Preferential trading arrangements are second best solutions, as shown by Meade $(1955,1956)$, Johnson $(1958)$ and others.

The key issue, therefore, in the light of the trend towards regionalism is whether RTAs will reinforce the multilateral free trade system and therefore should be welcomed, or whether they will undermine the system and deserve condemnation. Should regionalism be given priority by developing countries in view of the slow progress of the WTO-based multilateral approach?

\section{RTAs as Building Blocks}

Critics of the WTO-based multilateral approach to free trade who are frustrated with the slow progress made under the WTO in trade liberalization have translated the GATT acronym as a General Agreement to Talk and Talk. They have argued that RTAs among like-minded nations produce faster agreements on trade liberalization. It is suggested that certain disciplines must be observed to minimize the incidence of trade diversion. For example, that the common external tariff in a CU is not higher or more restrictive than the pre-CU level, that duties and regulations in an FTA are not higher than the pre-FTA level, and that greater discipline is exercised with regard to anti-dumping and VER actions.

Under the dynamic view of regionalism as a building block for multilateralism, the threat of regionalism could produce multilateral trade agreements that otherwise would have been held up. It was reported that one of the forces that prompted the eventual successful conclusion of the Uruguay Round in 1993 was the decision of the EU to form a Single Common Market in 1992. Thus, there could be a positive interaction between regional and global approach to trade liberalization.

In a political economy sense, negotiations and agreements where few parties are involved are easier to achieve than in situations where many parties are involved. There are over a hundred countries currently involved in the process of multilateral trade negotiation, which makes the achievement of agreements and resolutions under the Most Favoured Nation (MFN) principle much more complex and difficult than if negotiations are conducted with few parties under regional reciprocity. The free rider problem has constrained groups of countries to extend preferential arrangements under the MFN principle. 
Further, public support for a RTA tends to be more focused and mobilised than support for multilateralism. The politics of preferential trade arrangements implies that it is easier for businessmen to secure trade diversionary deals in a Free Trade Area or Customs Union than in the non-discriminatory world of GATT.

\section{RTAs as Stumbling Blocks}

On the other hand, supporters of the WTO approach have pointed to the slow implementation of an FTA or CU. For example, the European Community started in 1957 and the integration process has been slow. It took ASEAN ten years after its formation to draw up its agenda for economic cooperation, and 25 years to agree to establish an FTA. The ASEAN FTA immediately faced hitches in implementation and the time frame for implementation was reduced from 15 to ten years largely because the implementation of the Uruguay Round agreements would be completed within a ten-year time-frame.

RTA is designed to promote trade among its members at the expense of non-members. It therefore produces a trade-creating effect (generating trade with one more efficient member at the expense of another less efficient member) and a trade-diverting effect (taking trade away from efficient outside suppliers and giving it to inefficient member countries). Which effect would be dominant depends on the proportion of trade between members and non-members, on the expenditure share between imports and domestic production and on the elasticity of substitution between goods. It is not certain that the trade diversion effect is minimized if the regional trade arrangement is confined to proximate countries. ${ }^{4}$

Regionalism could also undermine multilateralism within the dynamic context. The unwillingness of the EC to start the multilateral trade negotiations in 1982 and its foot-dragging in the Uruguay Round reflect to some extent its availability of regionalism as an option. Under this scenario the world will be divided into three or two trading blocs.

So far, RTAs have been positive forces in driving global liberalization with initiatives to establish free trade between regional groupings. This goal of global free trade is quite feasible. As Table 1 shows, over 60 percent of world trade now occurs within regional groupings that have already achieved free trade such as the EU and Australia-New Zealand, or have signed an agreement to achieve it such as NAFTA and AFTA, or have made a political commitment to do so by a certain 
date, such APEC, the Free Trade of the Americas and EUROMED. On the other hand, the proliferation of regional arrangements could also make it difficult to maintain consistency with the global system. For example, the next potential regional arrangement, a Trans Atlantic Free Trade Area (TAFTA) between North America and Europe, could have a negative impact on the global trading system by encompassing new discrimination against the poor by the rich and thus reversing the progress towards North-South trade cooperation.

TABLE 1: Regional Free Trade Arrangements (Share of World Trade, $1994)^{\mathrm{a}}$

\begin{tabular}{|l|c|}
\hline European Union & $22.8 \%$ \\
\hline EUROMED & $2.3 \%$ \\
\hline NAFTA & $7.9 \%$ \\
\hline Mercosur & $0.3 \%$ \\
\hline Free Trade Area of the Americas & $2.6 \%^{\mathrm{b}}$ \\
\hline ASEAN Free Trade Area & $1.3 \%$ \\
\hline Australia-New Zealand & $0.1 \%$ \\
\hline APEC & $23.7 \% \mathrm{p}^{\mathrm{b}}$ \\
\hline TOTAL & $61.0 \%$ \\
\hline
\end{tabular}

Notes:

a Trade among the members of each regional group.

${ }^{\mathrm{b}}$ Excluding trade among the members of their own sub-regional groups.

Source: Bergsten (1996).

\section{Critical Factors for Making RTAs Building Blocks}

Given that there are positive as well as negative implications of RTAs for achieving global free trade, it is not certain how RTAs can contribute to achieving the goal of the WTO.

Arguably, whether regionalism will lead to a fragmented world economy or to non-discriminatory free trade through building blocks depends on the willingness of member governments, the behaviour of interest groups, the reactions of governments and interest groups in non-member countries and the types of rules of accession adopted.

RTAs can become building blocks if they are open to everyone and if everyone who wants to join is admitted on the same terms as the original members. RTAs can also become building blocks through mergers of blocks. This situation occurs when each economy forms a 
block with one neighbour. In the next stage the members of one agreement merge with those of another agreement and so on. This process continues until global free trade is reached. But will this happen, or are there circumstances in which the process will be curtailed? Some analysts, for example see Meade (1955), have found that the full process is possible, but only if the general level of inter-block tariffs is low enough to allow firms to make greater profits with unrestricted access to all markets. These two possibilities highlight the importance of having rules of accession and on the use of preferential agreements. These rules will place a discipline on preferential agreements, constraining the process in a particular direction. In the absence of these rules, the block will stop growing short of global free trade. That is, when block members are given discretion over who can join, they will stop letting in others before global free trade is reached.

\section{Should Regionalism be Given Priority over WTO-based Approach?}

Although there are inherent problems in the multilateral approach to global free trade, the approach by way of regionalism is also fraught with inherent costs and dangers.

There is a cost in having a series of bilateral and regional trade agreements in terms of the risk of complex rules of origin. As pointed out by Findlay (2001), the more dimensions there are to an agreement, the more scope there is to apply discrimination in a variety of ways and the more difficult it is to bolt together the agreements that emerge. The range of issues now being considered, such as services, standards and investment, add to the dimensions of the agreements. The outcome could be a bowl of noodles made up of the criss-crossing of agreements, of different content, applying different principles in resolving new issues. The cost of doing business could increase due to the inconsistencies between the various elements of the agreements, such as different schedules for phasing out tariffs, different rules of origin, exclusions, conflicting standards and differences in rules in dealing with anti-dumping and other regulations and policies. The more dimensions there are to the new agreements and the more agreements there are, the wider the scope for inconsistencies to emerge.

Apart from economic costs, there could also be political costs in having a series of bilateral trade deals. It has been argued that although the US-Singapore FTA could bring some indirect benefits for ASEAN 
countries, this bilateral trade pact could also present some risks and challenges for ASEAN as a preferential economic grouping. Singapore can be perceived by other ASEAN countries as providing a 'back door' for non-ASEAN countries to the region and thus as undermining the effectiveness of AFTA. Critics have alleged that Singapore's FTA partners will be able to gain tariff-free access into ASEAN markets through Singapore, without providing reciprocal access to the ASEAN countries (Asiaweek, 8 December 2000). Whether this perception is groundless or not, it could undermine Singapore's relationship with its ASEAN neighbors. The importance of the ASEAN region to Singapore cannot be overemphasized as it provides Singapore a hinterland and a source of raw materials and cheap labour. In addition, regional cooperation is the key to the resolution of the current political problems afflicting Singapore and the region. Singapore is also equally important to the ASEAN region economically and politically. The US-Singapore FTA must be seen as beneficial to the region and as contributing to the narrowing of the development gaps within ASEAN.

The multi-dimensional nature of the agreements can also be a source of problems if the consequence of the interaction is a set of hubs and spokes. Hub and spoke agreements do not provide equal access to all participants. Even if tariffs were removed in each spoke, the spoke countries would still not have free access to each other's markets. They only have access to the hub. The extent of access is also likely to vary among spokes. Thus, the benefits to the hub economy are quite obvious. It gains benefits from the preference it gets in access to the spoke economies and in terms of obtaining imports from the other spokes. The hub economy can also divert foreign investments from the spokes because foreign investors would have access to all the spokes in addition to the domestic market access of the host economy. The spokes lose since they do not gain from free trade with other spokes, they could be damaged by discrimination in other spoke markets and they might have a reduced ability to compete in all markets against firms based in the hub (Wonnacott 1996).

The growth of hub and spoke mechanisms could lead to a greater resistance to multilateral liberalization. It is argued that each spoke country has paid a price for its preferential access to the hub country. The spokes will resist further reductions of tariffs on an MFN basis which erode the value of their special deal on the sensitive products. For the same reason the current spokes would also resist the admission of new members to the arrangement since the value of their preferential access 
is diminished. This resistance may come not only from domestic interests in the spoke countries but also from foreign investors who might have invested in a spoke country for the purpose of access to the hub. Spokes may also have little say in the process of admission in which case the trade policy of the hub becomes a point of potential conflict among current and prospective members of the arrangement.

TABLE 2: A Large Share of Real Income Gains Comes from Lowering Barriers in Agriculture and Food

(real income gains in 2015 relative to the baseline 1997 \$billion)

\begin{tabular}{|c|c|c|c|}
\hline & \multicolumn{3}{|c|}{ Liberalizing region } \\
\hline & $\begin{array}{l}\text { Low and } \\
\text { middle- } \\
\text { income coun- } \\
\text { tries }\end{array}$ & $\begin{array}{l}\text { High-in- } \\
\text { come } \\
\text { countries }\end{array}$ & $\begin{array}{l}\text { All } \\
\text { coun- } \\
\text { tries }\end{array}$ \\
\hline & \multicolumn{3}{|c|}{ Decomposition of static impacts } \\
\hline $\begin{array}{c}\text { Gains to low- and middle-income countries } \\
\cdot \text { Agriculture and food } \\
\cdot \quad \text { Manufacturing } \\
\cdot \text { All merchandise trade }\end{array}$ & $\begin{array}{c}80 \\
33 \\
114\end{array}$ & $\begin{array}{l}20 \\
25 \\
44\end{array}$ & $\begin{array}{c}101 \\
58 \\
159\end{array}$ \\
\hline $\begin{array}{cl}\text { Gains to high-income countries } \\
\cdot \quad \text { Agriculture and food } \\
\cdot \quad \text { Manufacturing } \\
\cdot \quad \text { All merchandise trade }\end{array}$ & $\begin{array}{l}23 \\
44 \\
67\end{array}$ & $\begin{array}{l}64 \\
-3 \\
63\end{array}$ & $\begin{array}{c}91 \\
41 \\
132\end{array}$ \\
\hline $\begin{array}{l}\text { Global gains } \\
\cdot \quad \text { Agriculture and food } \\
\cdot \quad \text { Manufacturing } \\
\cdot \quad \text { All merchandise trade }\end{array}$ & $\begin{array}{c}103 \\
77 \\
181\end{array}$ & $\begin{array}{c}84 \\
22 \\
107\end{array}$ & $\begin{array}{c}193 \\
98 \\
291\end{array}$ \\
\hline . All merchandise trade & \multicolumn{3}{|c|}{ Decomposition of dynamic impacts } \\
\hline $\begin{array}{c}\text { Gains to low- and middle-income countries } \\
\cdot \text { Agriculture and food } \\
\cdot \quad \text { Manufacturing } \\
\cdot \text { All merchandise trade }\end{array}$ & $\begin{array}{c}167 \\
95 \\
265\end{array}$ & $\begin{array}{c}75 \\
9 \\
85\end{array}$ & $\begin{array}{l}240 \\
108 \\
349\end{array}$ \\
\hline $\begin{array}{cl}\text { Gains to high-income countries } \\
\cdot \quad \text { Agriculture and food } \\
\cdot \quad \text { Manufacturing } \\
\cdot \quad \text { All merchandise trade }\end{array}$ & $\begin{array}{l}19 \\
36 \\
55\end{array}$ & $\begin{array}{c}100 \\
13 \\
115 \\
\end{array}$ & $\begin{array}{c}117 \\
48 \\
169\end{array}$ \\
\hline $\begin{array}{l}\text { Global gains } \\
. \quad \text { Agriculture and food } \\
. \quad \text { Manufacturing } \\
. \quad \text { All merchandise trade }\end{array}$ & $\begin{array}{l}185 \\
131 \\
321\end{array}$ & $\begin{array}{c}174 \\
22 \\
199\end{array}$ & $\begin{array}{l}358 \\
156 \\
518\end{array}$ \\
\hline
\end{tabular}

Source: World Bank 2004 
The principle of reciprocity, on which RTAs are based, can also place the poor developing countries at a disadvantage or at worst get them left out of the preferential agreements. The quid pro quo arrangement implies that only countries with somewhat similar or closely similar levels of economic development will find it less difficult to forge some form of economic cooperation or integration. Thus, the principle of nondiscrimination can therefore work in favour of poorer countries.

The formation of new bilateral and regional FTAs is having significant effects on the world trading system. In these bilateral FTAs, liberalization commitments are incomplete, with implementation sometimes open-ended, and important sectors, such as agriculture, often largely excluded. ${ }^{5}$ For example, the Japan-Singapore FTA has set a bad precedent by excluding some agricultural products from trade liberalization; specifically, the Agreement excludes cut flowers and ornamental fish, Singapore's principal exports of agricultural products to Japan. It has been reported that Japan will push for a similar exclusion in future negotiations with countries such as Mexico, Korea and Australia. If such deals proliferate, it could become harder to secure multilateral reforms in agriculture, thus working against the developing countries, which are natural exporters of agricultural goods.

The World Bank in its Global Economic Prospects, 2004 gives an analysis of the potential economic gains that could be achieved with the reduction of trade barriers in the Doha round. According to this analysis (see Table 2), a successful Doha round could generate \$291 billion in global economic gains. ${ }^{6}$ Measured in static terms, some $\$ 159$ billion in additional income would be reaped by developing countries in 2015 and rich countries would gain around $\$ 132$ billion. The gains, which would raise income levels by 1.5 and 0.5 percent, respectively, for developing and rich countries, could be much higher if dynamic effects - such as an increase in productivity and increasing FDI - are taken into consideration. In developing countries, the dynamic gains (totaling \$349 billion) are some 120 percent higher than static gains. The dynamic gain (totaling $\$ 169$ billion) for rich countries is less dramatic, because of the low GDP weight of agriculture, for which protection is strongest. The reduction of trade barriers in agriculture and food yield a static gain of $\$ 193$ billion (in 2015), two thirds of the total static gains from merchandise trade reform of $\$ 291$ billion. More than 50 percent of these gains in agriculture and food, $\$ 101$ billion, are reaped by developing countries, of which 80 percent is the result of own-reform in these two sectors. In other words, reform of agriculture and food in rich countries would 
lead to a gain of some $\$ 20$ billion for developing countries as a whole. Manufacturing liberalization by rich countries would lead to gains of $\$ 25$ billion to developed countries and could potentially even lead to a small loss of $\$ 3$ billion to rich countries as increased market access by developing countries generates term-of-trade losses for rich countries.

Trade would increase sharply particularly in the most severely protected sectors: agriculture and food. Global merchandise trade would increase by about 10 percent (more than $\$ 800$ billion), but exports from developing countries would rise by 20 percent (nearly $\$ 540$ billion). The largest percentage increase in trade (nearly 50 percent) would occur in processed foods. Agricultural trade would rise by 32 percent. Developing countries should see an increase in their exports of textiles, clothing, and footwear, although its magnitude would depend on the final implementation of the Uruguay Round (World Bank 2004).

The number of poor would decline substantially. At the world level, the number of persons living on $\$ 1 /$ day or less would decline by 61 million, or 8 percent of the current forecast for 2015 of 734 million. The number living on $\$ 2 /$ day or less would decline by 144 million. The greatest reduction in absolute terms would come in Sub-Saharan Africa. The region's unskilled workers would see the largest percentage increase in nominal wages and decreases in the cost of living.

Brown, Deardorff and Stern (2003) offer another analysis of the potential welfare gains of the trade liberalization which is to be carried out in the Doha round. Their analysis estimates that global welfare would rise by $\$ 684$ billion. The United States, EU and EFTA, Japan, Canada, Australia and New Zealand would have a combined welfare gain of $\$ 227$ billion. The combined welfare gain of the developing and other countries would be $\$ 457$ billion. These estimates differ somewhat from those of the World Bank because of the different assumptions and different databases used in the two analyses.

The above-mentioned analyses indicate the significant potential economic gains to the world and to developing countries, in terms of income gains, increased trade and poverty reduction, if the Doha round had been successful. With the collapse of Cancun, the hope of the Doha round being successfully concluded is dim and the potential gains can turn out to be a real loss, especially to the developing countries.

Success at bilateral trade deals coupled with a lack of progress on the Doha round would gradually create a different kind of global integration. From an economic perspective, a 'spaghetti bowl' of bilateral trade agreements is much less desirable than progress towards multilateral 
free trade. As has been proved theoretically, multilateral trade liberalization has positive and often sizeable impacts on economic welfare in all of the industrialized and developing countries/regions. While regional and bilateral FTAs may be welfare-enhancing for the member countries directly involved, these welfare gains are considerably smaller then those resulting from multilateral trade liberalization, and, in any case, accrue in absolute terms primarily to the large industrialized countries. Thus, the benefits of FTAs to the developing-country partners appear somewhat limited. It is also the case that the regional and bilateral FTAs involve elements of trade diversion and are therefore detrimental to some non-member countries (Brown, Dearndorff and Stearn 2003).

Developing countries have much to gain from a multilateral trading system based on strong rules, both to protect them against pressures from more powerful countries and to help them improve their own trade and domestic policies. Thus, it is in their vital interest that the rulemaking be conducted within the WTO, where their limited leverage in bilateral negotiations with larger countries is not an impediment. The trend towards bilateralism and regionalism does not augur well for developing countries. Developing countries have much to lose if the Doha round were to fail. For the poorest countries in particular, the chances of getting from a bilateral deal with America what they failed to get from the Doha round are nil. With their weak economies and weak bargaining power in bilateral negotiations, poor countries will have little chance of reaching FTAs with the rich countries and major regional groups. Thus they will be excluded from major markets.

At Cancun, it was reported that a group of poor countries, most of them from Africa, feared that freeing farm trade would mean losing their special preferences (The Economist, 18 September 2003). This section discusses how well trade preferences are serving developing countries and the implications of continuing with the preferences if the Doha round is not successfully concluded.

Most favourable and differential treatment of developing countries is a prominent feature of multilateral trade rules. Selected subsets of developing countries have been granted trade preferences. However, the present patchwork system has not worked especially well and trade preferences have had a limited impact on the exports of the beneficiary countries. Among the reasons, the following are especially important.

Countries benefiting from trade preferences have generally under-performed in exports. One reason is that rich countries granted preferences voluntarily rather than as part of a binding multilateral 
negotiation. Those preferences, often laden with restrictions, product exclusions and administrative rules, prevent beneficiaries from taking full advantage of them. For example, only 39 percent of potentially preferred imports under the Generalized System of Preferences (GSP) into the Quad countries (Canada, the EU, Japan, and the United States) actually took advantage of preferential access. The usage rates are declining (World Bank 2004). Besides GSP, the Quad countries also sponsor their own 'deep preference' programmes such as the EU's Everything But Arms programme and the U.S. African Growth and Opportunity Act. However, each has different rules and exceptions. For these reasons, preferences cover only a portion of exports from even poor developing countries. Even when effective, preferences tend to divert trade away from other poor countries.

Existing preferences do relatively little for most of the world's poorest people (those living on less than $\$ 1$ per day), most of whom live in China, India, Nigeria, Pakistan, Northeast Brazil, and some ASEAN countries, which may enjoy only partial preferences at best. Although some of these countries enjoy limited preference access to some markets, all would be better off with across-the-board, non-discriminatory binding access under the WTO rules.

The extensive use of voluntary preference schemes has created perverse incentives in both rich and poor countries to avoid liberalization that would otherwise benefit the poor. Too often, rich countries have offered differential treatment to a subset of poor countries instead of arriving at MFN reductions in trade barriers that would benefit all developing countries. Trade preferences have also been used as a defence by developed countries against genuine, multilateral liberalization in products of potential comparative advantage of developing countries. ${ }^{7}$ The preferences discourage liberalization within the beneficiary countries themselves. The present system of preferences reduces the incentive to negotiate effectively for reductions in trade barriers abroad and with domestic protectionist constituencies at home. This is either because they believe that they will not receive any further concessions in the multilateral process or because of concerns about erosion of preferences.

Because the preference schemes are not under the discipline of the WTO and they are offered as privileges, they frequently (a) exclude precisely those products in which developing countries have a comparative advantage, (b) 'graduate' a country out of the preference for a product just as it begins to achieve significant success as an exporter, and (c) attach side conditions that amount to reciprocal concessions from 
developing countries. (The original concept of GSP precludes reciprocal concessions from developing countries). These side conditions relating to labour, to the environment and to the grant of significant preferences introduce a certain element of uncertainty for exporters. The benefits may be withdrawn any time on the pretext that a specific standard is not being fulfilled. This deters potential entrepreneurs from making the necessary investments.

To take advantage of a tariff preference, an exporting country must satisfy certain 'rules of origin' to substantiate the claim that it indeed produced the goods rather than import them from another one excluded from GSP privileges. The commonest rule makes the preference contingent on a minimum value addition to the product by the exporting countries. This requirement can be a major deterrent since many small and poor countries are able to perform only simple assembly operations, so that they may not be able to satisfy the rules of origin. In contrast, richer and larger developing countries may succeed in satisfying these rules and be better able to take advantage of the preference. The ruleof-origin requirements and related inspection procedures can be quite costly. The associated paperwork and administrative requirements are likely to be a major reason that many eligible products do not enter developed-country markets under the preference provisions. Instead exporters pay the applicable MFN tariff.

Most of the academic research on preference programmes (for example see Panagariya 2002) has concluded not only that they generally yield modest export increases at best, but also that a significant portion of these gains is from trade diversion from non-beneficiaries. Therefore it is more important than ever to complete the Doha round of negotiations, bringing trade barriers down in developed and developing countries on a non-discriminatory basis. Such liberalization will not only promote genuine free trade but also remove the uncertainty associated with one-way trade preferences, reduce the existing discrimination across countries and help clean up the spaghetti-bowl phenomenon that now characterizes the trading system (Panagariya 2002). Because of the weaknesses and ineffectiveness of the preference schemes, they will continue to have a little impact on the exports of developing countries if the Doha round is not successfully concluded.

\section{Conclusion}

Despite the limitations of the WTO process in achieving global free trade, it is still a relevant organization. RTAs should remain a second 
best policy option. Countries and in particular developing countries of ASEAN should remain primarily committed to the ideals and modus operandi of the WTO.

In the face of the recent spurt of interest in regionalism, ASEAN countries should adopt a pragmatic approach. They should continue to place the highest priority on the multilateral trading system promoted by the WTO, as countries can only prosper if goods and services can flow freely with minimum impediments within a rule-based global trading framework. At the same time, since countries are closely tied to their neighbours, it is in their interest to help promote deeper regional economic integration to enhance competitive strength and attractiveness. By meeting the conditions and guiding principles set by the WTO for the formation of an RTA, we can also create the conditions for the RTAs to accelerate the momentum of trade liberalization further without hurting trade positions under the WTO framework.

Dr. Jose L. Tongzon is Associate Professor of Economics at the Department of Economics, National University of Singapore.

\section{NOTES}

* Acknowledgements. This paper was presented at the $6^{\text {th }}$ ASEAN Inter-University Seminar on Social Development, 14-16 May 2004, Universiti Sains Malaysia, Penang, Malaysia. The author is grateful for the useful comments and suggestions made by the referees on the first draft of this paper.

1 Nine years ago, the leaders of 34 countries in the Americas (all of them except Cuba) unveiled a bold vision of free trade from Alaska to Argentina. The accord is supposed to be finalized by December 2004.

2 The Mercusor was created by Argentina, Brazil, Paraguay and Uruguay in March 1991. The EU and the Mercusor countries signed a Framework Agreement in 1995 in preparation for negotiations for trade liberalization based on WTO rules. The two regional blocks completed the $10^{\text {th }}$ rounds of bioregional negotiations in June 2003.

3 The phrase 'building or stumbling blocks' is owed to Bhagwati (1991: 77) who refers to the expansion of membership as a test of preferential trading arrangements (PTA) serving as building blocks for global freeing of trade. He also pointed out that if going down the PTA path itself can trigger multilateral negotiations and their successful conclusion, that too can be a way in which PTAs may serve as building blocks.

4 For a more detailed discussion of this issue, see Bhagwati (1996).

5 This is because of the nature of preferential agreements which are based on the principle of reciprocity, allowing countries more scope for excluding politically sensitive industries from liberalization.

6 The assumption used in this analysis can be found in the World Bank, 2004.

7 In some cases trade preferences are given to developing countries mainly for political reasons. 


\section{REFERENCES}

Asiaweek, 'Keeping up with the Singaporeans', 8 December 2000: 22.

Bergsten, C. Fred 1996. A New Vision for the World Trading System. Paper presented at the World Trade Congress, Singapore, 24 April.

Bhagwati, Jagdish 1991. The World Trading System at Risk. Princeton: Princeton University and Harvester Wheatsheaf.

-1996. Preferential Trading Areas and Multilateralism: Strangers, Friends or Foes? Paper presented at the Staff Seminar, National University of Singapore, 19 September.

Brown, U.K., A.V. Deardorff and Robert M. Stern 2003. 'Multilateral, Regional and Bilateral Trade-Policy Options for the United States and Japan.' The World Economy, Vol. 26 (6): 803-828.

Findlay, Christopher 2001. 'Old issues in new regionalism.' Pacific Economic Papers, Australia-Japan Research Centre, Australian National University.

Johnson, Harry G. 1958. International Trade and Economic Growth: Studies in Pure Theory. London: Allen \& Unwin.

Kemp, M. C. 1962. 'The Gain from International Trade', Economic Journal, Vol. 72 (December): 803-19.

Meade, Edward James 1955. The Theory of Customs Union. Amsterdam: North-Holland.

-1956. A Geometry of International Trade. London: Allen \& Unwin.

Panagariya, Arvin 2002. 'EU Preferential Trade Arrangements and Developing Countries.' The World Economy, Vol. 25(10): 1415-32.

Samuelson, P. A. 1939. 'Gains from International Trade.' Canadian Journal of Economics and Political Science, Vol. 5 (May): 195-205.

The Business Times, 23 September 2003.

The Economist, 'WTO Under Fire', 18 September 2003.

Wonnacott, Ronald 1996. 'Trade and Investment in a Hub-and-Spoke System Versus a Free Trade Area.' The World Economy, Vol. 19(3): 237-252.

World Bank 2000. Trade Blocs. World Bank Policy Research Report, August.

- 2004. Global Economic Prospects.

World Trade Organization 1995. Regionalism and the World Trading System. 